\title{
Effect of Thinning Practices on Fruiting of Ruby Seedless Grapevine
}

\author{
Radwan, E.M.A. ${ }^{1}$ and A.A.B. Masood $^{2}$
}

${ }^{1}$ Horticultural Dept., Fac. Agric. Assiut University, The New Valley Branch, Egypt.

${ }^{2}$ Pomology Dept., Fac. Agric., Assiut University, Assiut, Egypt.

Received on: $28 / 5 / 2017$

Accepted for publication on: 13/6/2017

\section{Abstract}

This study was carried out during the two successive seasons of 2015 and 2016 at the Experimental Orchard Faculty of Agriculture, Assiut University, Assiut, Egypt, to investigate the effect of cluster or berry thinning on fruiting of Ruby Seedless grapevines. Thinning treatments were performed after berry set. The experiment was arranged in randomized set up as complete block with eight treatments and three replicates one vine per each.

- Fruit thinning by removing either 20 or $30 \%$ of cluster number/vine, as well as removing $30 \%$ of cluster shoulders considerably decreased the yield. Yield was unaffected carrying out by other thinning treatments compared to unthinned ones (control).

- Removing 20 or $30 \%$ of cluster number was responsive for increasing the cluster weight. Contrarly removed $30 \%$ of cluster shoulders materially deceased cluster weight, whereas cluster weight was unaffected by other thinning treatment compared to control.

- The best cluster compactness coefficient and form was obtained due berry thinning as removing $15 \%$ of its shoulders combined by $15 \%$ of cluster apical removal.

- All berry thinning improved the grapes quality in terms of increasing berry weight, berry coloration, total soluble solid and sugar contents and decreasing titratable acidity compared to control.

From this study, it is clear that to get the high yield with good clusters and berry traits it is preferable for carrying out berry thinning by removing $15 \%$ of cluster shoulders along with cutting back $15 \%$ from the apical cluster or cutting back about $30 \%$ of the apical portion of the cluster.

Keywords: Fruit thinning, Yield, Fruit quality, Ruby Seedless, Grapevine.

\section{Introduction}

Grapes are suggested to be one of he most important fruit crops for consumption and export. In Egypt, the average total production of grape is 1.596.169 tones (FAO, 2014). About $63 \%$ of the total grape production is located in the new reclaimed soils; however, only $37 \%$ are planted in the old soils. Generally, grapes is more favorable for human due to its excellent flavor, taste and its high essential nutrient contents (Coombe and
McCarthy, 2000). There are several practices should be performed carefully on grapevine to attain high production and high quality. Among these practices, thinning which is very important to control the yield and improve the clusters size order to promoting ripening, and incrase its contents of sugar, anthocyanin stain and berries sizes (Palliotti Cartechini and 2000, Selim, 2007, El-Salhy et al., 2010 and Vicente and Yuste, 2015). Fruit thinning may be neces- 
sary or recommended in plants with overload and/or under adverse weather conditions. It can help to achieve the desired status of maturity, if it is done early enough before harvest. The reduction of crop modifies the source-sink ratio and can facilitate the advancement of ripening (Palliotti and Cartechini, 2000). Berry thinning has been used to obtain the needed loosened, large berries, highest berry weight and accerated ripening. The thinning necessary depended on the cultivar and sunshine as well as temperature and nutrient supply (Poni, 2003; Cheema et al., 2003 and ElSalhy et al., 2010). Several thinning practices are available, i.e., hand clusters thinning, which is expensive, and needs intensive field works. Hand thinning plays an important role in some grape varieties, since its control crop and improves its quality and hastens the ripening (Dhillon et al., 1992; Fitzgerold and Patterson, 1994; Keller et al., 2005; Selim, 2007; Diago et al., 2010 and El-Salhy et al., 2010). Mechanical clusters thinning (Petrie and Clingeleffer, 2006; Tardaguila et al., 2008 and Vicente and Yuste, 2015) and chemical thinning by using specific chemical agents, i.e., ethephon, gibberellic acid and naphthalene acetic acid (Kokl and Ball, 2017). However, potential risk might be occurred due to the use of the above mentioned chemicals. Therefore, the other mentioned methods are recognized as an environmental friendly and methods. It is broadly believed in grape production that high yielding grapevines produce lower quality berries and grape growers take some measures to assure their grape quality.
So, the objective of present work was to study the effect of cluster and berry thinning on fruiting of Ruby Seedless grapevines.

\section{Materials and Methods}

This study was carried out during two successive seasons of 2015 and 2016 on Ruby Seedless grapevines. All grapevines were 16 years old at the beginning of the experiment spaced at $2 \times 2.5 \mathrm{~m}$, grown at experimental orchard, Faculty of Agriculture, Assiut University, Egypt. The vines were trained as traditional double cordon with three wires and pruned during the end week of January. Each vine was pruned to four arms of four fruiting spurs with 2 buds lenth, a total 32 buds/vine. Crop load at all vines was adjusting to 30 $\& 24$ and 21 clusters/vine after berry set, respectively. The selected vines were divided into eight different thinning including the control. The experiment was arranged in randomized complete block design with three replications per treatment one in vine each. Thus the treatments were arranged as follow:

1- Leaving 30 clsuters/vine without fruit thinning (control).

2- Thinning by removing $20 \%$ of cluster numbers (24 cluster/vine).

3 - Thinning by removing $30 \%$ of cluster numbers (21 cluster/vine).

4- Thinning by alternatively removing about $15 \%$ from cluster branches (laterals).

5- Thinning by cutting back about $15 \%$ from the apical clusters portion.

6- Thinning by alternatively removing about $30 \%$ from cluster branches (laterals). 
7- Thinning by cutting back about $30 \%$ from the apical clusters portion.

8- Thinning by cutting back about $15 \%$ from cluster branches (laterals), plus cutting back about $15 \%$ from the apical clusters portion.

Thinning treatments were performed after berry set by using special shears. At harvesting date, when total soluble solids (TSS\%) attained (16-18\%) and color development is $80 \%$. Three clusters were taken at random from the yield of each vine to determine of some physical and chemical fruit properties, weight of cluster (g), as well as cluster length (cm) and number of berries per cluster, then cluster compactness was estimated coefficient according to Winkler et al. (1974). In addition, chemical properties i.e. TSS, reducing sugars and total acidity were determine according to the procedures that outlined A.O.A.C. (1985). Also, total anthocyanin was determined according to Marrkham (1982). Data were subjected to statistical analysis according to the procedure reported by Gomez and Gomez (1984) and
Snedecor and Cochran (1990). Treatments means were compared by using the least significant difference test (New L.S.D.) at the $5 \%$ level of probability in the two experimental seasons.

\section{Results}

1- Effect of thinning treatment on yield and cluster traits:

Data in Table (1) show the thinning treatment effects on yield/vine of Ruby Seedless grapevines during 2015 and 2016 seasons. It is obvious from the data that the results took similar trend during the two studied seasons.

Data in Table (1) declared that the thinning by removing either $20 \%$ $\left(\mathrm{T}_{2}\right)$ or $30 \%$ of cluster number/vine $\left(\mathrm{T}_{3}\right)$, also, removed $30 \%$ of shoulders $\left(\mathrm{T}_{6}\right)$ significantly decreased the yield/vine compared to unthinned ones. Meanwhile, other berry thinning, whatever, removing $15 \%$ of cluster shoulders (T4), 15\% $\left(\mathrm{T}_{5}\right)$, $30 \%$ of cluster apical $\left(\mathrm{T}_{7}\right)$, or thinning by $15 \%$ of shoulders combined with $15 \%$ of cluster apical $\left(\mathrm{T}_{8}\right)$ unsignificantly affected the yield/vine compared to unthinned ones $\left(T_{1}\right)$.

Table 1. Effect of fruit thinning practices on the cluster weight and yield/vine of Ruby Seedless grapevines during 2015 and 2016 seasons.

\begin{tabular}{|c|c|c|c|c|c|c|}
\hline \multirow{2}{*}{ Treatment } & \multicolumn{3}{|c|}{ Yield/vine } & \multicolumn{3}{|c|}{ Cluster weight } \\
\hline & 2015 & 2016 & Mean & 2015 & 2016 & Mean \\
\hline Leaving 30 clust. $\left(T_{1}\right)$ & 10.70 & 9.74 & 10.22 & 357.00 & 324.53 & 340.77 \\
\hline Leaving 24 clust. $\left(\mathrm{T}_{2}\right)$ & 9.63 & 8.51 & 9.07 & 401.18 & 354.72 & 377.95 \\
\hline Leaving 21 clust. $\left(\mathrm{T}_{3}\right)$ & 8.85 & 8.00 & 8.43 & 421.10 & 381.30 & 401.20 \\
\hline Rem. $15 \%$ of clust. bran. $\left(\mathrm{T}_{4}\right)$ & 10.91 & 9.62 & 10.26 & 363.67 & 320.58 & 342.13 \\
\hline Cut. $15 \%$ of apical clust. $\left(\mathrm{T}_{5}\right)$ & 11.16 & 9.76 & 10.45 & 371.88 & 325.44 & 348.66 \\
\hline Rem. $30 \%$ of clust. bran. $\left(\mathrm{T}_{6}\right)$ & 9.56 & 8.88 & 9.22 & 318.50 & 296.14 & 307.32 \\
\hline Cut. $30 \%$ of apical clust. $\left(\mathrm{T}_{7}\right)$ & 10.50 & 9.38 & 9.94 & 349.18 & 310.25 & 329.78 \\
\hline Rem. $15 \%$ plus cut. $15 \%\left(\mathrm{~T}_{8}\right)$ & 10.65 & 9.60 & 10.13 & 358.40 & 319.56 & 338.98 \\
\hline New LSD & 0.53 & 0.46 & & 22.72 & 18.56 & \\
\hline
\end{tabular}


Table 2. Effect of fruit thinning practices on the number of berries/cluster, cluster length (cm) and compactness coefficient of Ruby Seedless grapevines during 2015 and 2016 seasons.

\begin{tabular}{|l|c|c|c|c|c|c|c|c|c|}
\hline \multirow{2}{*}{ Treat. } & \multicolumn{3}{|c|}{$\begin{array}{c}\text { No. of } \\
\text { berries/cluster }\end{array}$} & \multicolumn{3}{c|}{$\begin{array}{c}\text { Cluster length } \\
\text { (cm) }\end{array}$} & \multicolumn{3}{c|}{$\begin{array}{c}\text { Compactness } \\
\text { coefficient }\end{array}$} \\
\cline { 2 - 10 } & $\mathbf{2 0 1 5}$ & $\mathbf{2 0 1 6}$ & Mean & $\mathbf{2 0 1 5}$ & $\mathbf{2 0 1 6}$ & Mean & $\mathbf{2 0 1 5}$ & $\mathbf{2 0 1 6}$ & Mean \\
\hline Leaving 30 clust. ( $\left.\mathrm{T}_{\mathbf{1}}\right)$ & 199.00 & 183.60 & 191.30 & 28.00 & 23.30 & 25.65 & 7.10 & 7.88 & 7.49 \\
Leaving 24 clust. ( $\left.\mathrm{T}_{\mathbf{2}}\right)$ & 210.67 & 198.70 & 204.69 & 26.65 & 25.07 & 26.86 & 7.69 & 7.93 & 7.89 \\
Leaving 21 clust. ( $\left.\mathrm{T}_{\mathbf{3}}\right)$ & 221.75 & 203.55 & 212.65 & 29.72 & 25.06 & 27.39 & 7.46 & 8.12 & 7.79 \\
Rem. 15\% of clust. bran. $\left(\mathrm{T}_{\mathbf{4}}\right)$ & 178.12 & 162.80 & 170.46 & 27.50 & 22.84 & 25.17 & 6.40 & 7.13 & 6.77 \\
Cut. 15\% of apical clust. $\left(\mathrm{T}_{\mathbf{5}}\right)$ & 178.65 & 157.87 & 168.26 & 23.93 & 19.76 & 21.85 & 7.46 & 7.98 & 7.72 \\
Rem. 30\% of clust. bran. $\left(\mathrm{T}_{\mathbf{6}}\right)$ & 165.77 & 146.73 & 156.25 & 28.10 & 23.67 & 25.89 & 5.90 & 6.20 & 6.05 \\
Cut. 30\% of apical clust. $\left(\mathrm{T}_{\mathbf{7}}\right)$ & 161.00 & 146.56 & 156.78 & 19.55 & 16.30 & 17.93 & 8.23 & 8.62 & 8.43 \\
Rem. 15\% plus cut. 15\% $\left(\mathrm{T}_{\mathbf{8}}\right)$ & 165.48 & 143.10 & 154.29 & 24.10 & 20.38 & 22.24 & 6.87 & 7.02 & 6.94 \\
\hline \multicolumn{1}{|c|}{ New LSD } & 10.78 & 8.84 & & 0.84 & 0.72 & & 0.36 & 0.43 & \\
\hline
\end{tabular}

The obtained yield was (9.07, 8.43 and $9.22 \mathrm{~kg}$ as an av. of the two studied seasons) due to $\mathrm{T}_{2}, \mathrm{~T}_{3}$ and $\mathrm{T}_{6}$, respectively. Contrarly, the yield of unthinned ones $\left(\mathrm{T}_{1}\right)$ was $(10.22$ $\mathrm{kg} / \mathrm{vine})$. Hence the corresponding decrement percentage of yield under the $\left(\mathrm{T}_{1}\right)$ were attained $(11.25,17.51$ $\& 9.78 \%$ as an av. of the two studied seasons), respectively.

Moreover, data in Tables ( 1 \& 2) showed that a significantly increased in cluster weight due to remove 20 or $30 \%$ of cluster number/vine compared to unthinned ones (control, $\mathrm{T}_{1}$ ). Contrarly removed $30 \%$ of cluster shoulders $\left(\mathrm{T}_{6}\right)$ significantly decreased cluster weight compared to control and other treatments. whereas, other treatments $\left(\mathrm{T}_{4}, \mathrm{~T}_{5}, \mathrm{~T}_{7}\right.$ $\& \mathrm{~T}_{\mathbf{8}}$ ) had unsignificantly affected on cluster weight compared to control $\left(\mathrm{T}_{1}\right)$. The obtained cluster weight was (340.77, 377.95, 401.20, 342.13, $348.66,307.32,329.78$ and $338.98 \mathrm{~g}$ as an av. the two studied seasons) due to $T_{1}$ to $T_{8}$, respectively. The corresponding increment percentage of cluster weight attained $(10.91 \&$ $17.73 \%$ ) due to $T_{2}$ and $T_{3}$ and reduction percentage attained $(9.82 \%)$ due to $\mathrm{T}_{6}$ comparing with control $\left(\mathrm{T}_{1}\right)$, respectively.

Also, date in the previously tables cleared that removing either $20 \%$ or $30 \%$ of cluster number/vine significant increase the berries number per cluster and cluster length, then consequently unsignificantly affected the cluster compactness coefficient compared to unthinned one (control, $\left.\mathrm{T}_{1}\right)$. Contrarly, all berry thinning $\left(\mathrm{T}_{4}\right.$, $\mathrm{T}_{5}, \mathrm{~T}_{6}, \mathrm{~T}_{7}$ and $\mathrm{T}_{8}$ ) significantly decreased the berries number per cluster, whereas, $\mathrm{T}_{5}, \mathrm{~T}_{7}$ and $\mathrm{T}_{\mathbf{8}}$ significantly decreased the cluster length compared to control. Hence, the compactness coefficient of cluster significantly decreased due to remove $15 \%\left(\mathrm{~T}_{4}\right)$ or $30 \%$ cluster shoulders $\left(\mathrm{T}_{6}\right)$ as well as removing $15 \%$ of cluster shoulders combined with $15 \%$ of cluster apical of removal and significant increased by removing $30 \%$ of cluster apical $\left(\mathrm{T}_{7}\right)$. On other hand, other berry thinning treatments $\left(\mathrm{T}_{5} \&\right.$ $\mathrm{T}_{\mathbf{8}}$ ) unsignificantly affect the cluster compactness coefficient compared to control $\left(\mathrm{T}_{1}\right)$.

The recorded compactness coefficient of cluster was $(7.49,7.81$, $7.79,6.77,7.72,6.05,8.43$ and 6.94 
as an av. of the two studied seasons) due to $T_{1}$ to $T_{8}$, respectively. The decrement percentage of cluster compactness coefficient was $(9.61,19.23$ $\& 7.34 \%$ ) due to $\mathrm{T}_{4}, \mathrm{~T}_{6} \& \mathrm{~T}_{8}$ and increment percentage of it was $(12.55 \%)$ due to remove $30 \%$ of cluster apical $\left(\mathrm{T}_{7}\right)$ compared to control $\left(\mathrm{T}_{1}\right)$, respectively.

\section{2- Effect of thinning treatment on berry quality:}

Data present in Tables ( $3 \& 4)$ indicated that either cluster thinning or berry thinning as any methods significantly improved the Ruby Seedless grapes quality in terms of berry weight, total soluble solid, reducing sugars, TSS/acid ratio and anthocyanin in berry skin and decreasing titratable acidity $\%$. The heaviest berry weight was recorded on berries of vines that berry thinning by removing $15 \%$ of shoulders combined with $15 \%$ of cluster apical $\left(\mathrm{T}_{8}\right)$. Also, the highest values of total soluble solids, reducing sugars and anthocyanin contents were recorded due to berry thinned by cutting back $30 \%$ cluster apical $\left(\mathrm{T}_{7}\right)$.
The obtained ten berries weight was $(15.46,18.08,19.38,19.19$, $19.14,20.34,20.52$ and $21.00 \mathrm{~g}$ as an av. the two studied seasons) due to $T_{1}$ to $\mathrm{T}_{\mathbf{8}}$, respectively. The corresponding increment percentage of berry weight was $(16.95,25.35,24.13$, $23.80,31.16,32.73 \& 39.72 \%$ ) due to $\mathrm{T}_{2}$ to $\mathrm{T}_{8}$ compared to $\mathrm{T}_{1}$, respectively.

Similarly the values of TSS were $(17.30,18.78,19.05,18.60$, $18.90,18.83,19.00$ and $18.77 \%$ ) as well as, anthocyanin in berry skin were $(1.49,1.86,1.88,1.86,1.90$, $1.90,1.91$ and $1.88 \mathrm{mg} / \mathrm{g}$ as an av. the two studied seasons) due to $\mathrm{T}_{1}$ to $\mathrm{T}_{\mathbf{8}}$, respectively. Hence, the corresponding increment percentage of TSS attained $(8.55,10.12,7.51,9.25,8.84$, 9.83 and $8.50 \%$ ) and anthocyanin $(24.83,26.17,24.48,27.52,27.52$, 28.19 and $26.17 \%$ ) due to $\mathrm{T}_{2}$ to $\mathrm{T}_{8}$ compared to unthinned ones (control, $\mathrm{T}_{1}$ ), respectively. No significant differences in chemical juice properties due to any thinning treatments.

Table 3. Effect of fruit thinning practices on weight 10 berries (g), reducing sugars \% and anthocyanin (mg/g) of Ruby Seedless grapes during 2015 and 2016 seasons.

\begin{tabular}{|l|c|c|c|c|c|c|c|c|c|}
\hline \multirow{2}{*}{ Treat. } & \multicolumn{3}{|c|}{ Weight 10 berries $(g)$} & \multicolumn{2}{c|}{ Reducing sugars \% } & \multicolumn{3}{c|}{ Anthocyanin (mg/g) } \\
\cline { 2 - 10 } & $\mathbf{2 0 1 5}$ & $\mathbf{2 0 1 6}$ & Mean & $\mathbf{2 0 1 5}$ & $\mathbf{2 0 1 6}$ & Mean & $\mathbf{2 0 1 5}$ & $\mathbf{2 0 1 6}$ & Mean \\
\hline Leaving 30 clust. $\left(\mathrm{T}_{\mathbf{1}}\right)$ & 16.24 & 14.67 & 15.46 & 13.07 & 13.88 & 13.33 & 1.38 & 1.59 & 1.49 \\
Leaving 24 clust. $\left(\mathrm{T}_{\mathbf{2}}\right)$ & 17.85 & 18.31 & 18.08 & 15.09 & 15.77 & 15.43 & 1.98 & 1.73 & 1.86 \\
Leaving 21 clust. $\left(\mathrm{T}_{\mathbf{3}}\right)$ & 19.21 & 19.55 & 19.38 & 15.46 & 15.92 & 15.69 & 2.06 & 1.70 & 1.88 \\
Rem. 15\% of clust. bran. $\left(\mathrm{T}_{\mathbf{4}}\right)$ & 18.95 & 19.53 & 19.19 & 14.89 & 15.61 & 15.26 & 1.93 & 1.79 & 1.86 \\
Cut. 15\% of apical clust. $\left(\mathrm{T}_{\mathbf{5}}\right)$ & 18.67 & 19.61 & 19.14 & 15.55 & 15.76 & 15.66 & 2.01 & 1.78 & 1.90 \\
Rem. 30\% of clust. bran. $\left(\mathrm{T}_{\mathbf{6}}\right)$ & 20.18 & 20.51 & 20.34 & 14.81 & 15.61 & 15.21 & 1.95 & 1.83 & 1.90 \\
Cut. 30\% of apical clust. $\left(\mathrm{T}_{7}\right)$ & 20.48 & 20.56 & 20.52 & 15.53 & 15.98 & 15.76 & 2.06 & 1.76 & 1.91 \\
Rem. 15\% plus cut. 15\% $\left(\mathrm{T}_{\mathbf{8}}\right)$ & 20.90 & 21.10 & 21.00 & 14.88 & 15.45 & 15.16 & 2.02 & 1.73 & 1.88 \\
\hline \multicolumn{1}{|c|}{ New LSD } & 0.65 & 0.53 & & 0.58 & 0.64 & & 0.05 & 0.04 & \\
\hline
\end{tabular}


Table 4. Effect of fruit thinning practices on the total soluble solids (TSS\%), acidity \% and TSS/acid ratio of Ruby Seedless grapes during 2015 and 2016 seasons.

\begin{tabular}{|l|c|c|c|c|c|c|c|c|c|}
\hline \multirow{2}{*}{\multicolumn{1}{|c|}{ Treat. }} & \multicolumn{3}{|c|}{ T.S.S. } & \multicolumn{3}{c|}{ Acidity \% } & \multicolumn{3}{c|}{ TSS/acid ratio } \\
\cline { 2 - 10 } & $\mathbf{2 0 1 5}$ & $\mathbf{2 0 1 6}$ & Mean & $\mathbf{2 0 1 5}$ & $\mathbf{2 0 1 6}$ & Mean & $\mathbf{2 0 1 5}$ & $\mathbf{2 0 1 6}$ & Mean \\
\hline Leaving 30 clust. $\left(\mathrm{T}_{\mathbf{1}}\right)$ & 16.80 & 17.80 & 17.30 & 0.46 & 0.48 & 0.47 & 36.52 & 37.08 & 36.80 \\
Leaving 24 clust. $\left(\mathrm{T}_{\mathbf{2}}\right)$ & 18.47 & 19.08 & 18.78 & 0.39 & 0.39 & 0.39 & 47.36 & 48.92 & 48.14 \\
Leaving 21 clust. $\left(\mathrm{T}_{\mathbf{3}}\right)$ & 18.80 & 19.30 & 19.05 & 0.38 & 0.40 & 0.39 & 49.47 & 48.25 & 48.86 \\
Rem. 15\% of clust. bran. $\left(\mathrm{T}_{\mathbf{4}}\right)$ & 18.10 & 19.10 & 18.60 & 0.37 & 0.39 & 0.38 & 48.92 & 48.97 & 48.95 \\
Cut. 15\% of apical clust. $\left(\mathrm{T}_{\mathbf{5}}\right)$ & 18.50 & 19.30 & 18.90 & 0.38 & 0.40 & 0.40 & 48.68 & 48.25 & 48.46 \\
Rem. 30\% of clust. bran. $\left(\mathrm{T}_{\mathbf{6}}\right)$ & 18.50 & 19.16 & 18.83 & 0.38 & 0.39 & 0.39 & 48.68 & 49.12 & 48.90 \\
Cut. 30\% of apical clust. $\left(\mathrm{T}_{\mathbf{7}}\right)$ & 18.70 & 19.30 & 19.00 & 0.39 & 0.41 & 0.40 & 47.95 & 47.07 & 47.51 \\
Rem. 15\% plus cut. 15\% $\left.\mathrm{T}_{\mathbf{8}}\right)$ & 18.44 & 19.10 & 18.77 & 0.37 & 0.39 & 0.38 & 49.84 & 48.97 & 49.40 \\
\hline \multicolumn{1}{|c}{ New LSD } & 0.72 & 0.78 & & 0.02 & 0.03 & & 1.44 & 1.58 & \\
\hline
\end{tabular}

\section{Discussion and Conclusion}

Thinning as removing some of cluster branches induce a reduction of number of berries, so the compactness coefficient of cluster was decrease. The purpose is to give individual berries enough space to fully develop and still have a fruit cluster that is not too compact so, that high quality berry is produced. Hence, there was correlated positively between percentage of removing cluster shoulders and its compactness coefficient. The decreasing in berries number surely reflected in decreasing the cluster weight, consequently reduce the yield/vine.

In addition, reducing the berries number per cluster without changing the number of leaves, which reduce the competition between the berries on essential materials which lead to increase berry weight.

So, it can be concluded that the berry thinning accumulated carbohydrates content, which activate the process of growth and development, hence increased the berry weight and hastened ripening. These reflected on advancing the berry ripening and improving its quality for increasing sug- ars and soluble solid contents and decreasing total acidity.

Therefore, one can be concluded that berries thinning must be done to improve the clusters and berries attributes of Ruby seedless grapes. Since, now improve in clusters and berries quality are most important target than total yield as grape quality, since results an increase in packable.

The results are in agreement with these obtained by many research workers, such as Dhillon et al. (1992), Rizk (1998), El-Hammady et al. (2000), Dhillon and Bindra (2002), Abdel-Galil and El-Wasfy (2003), Singh and Singh (2003), Mohsen-Abeer (2005), Selim (2007), Hussein, Maha (2008) and El-Salhy et al. (2010).

The reduction of cluster number vine as cluster thinning has been reduced the yield per vine. Contrary the cluster weight tended to increase when clusters per vine were reduced by more than yield per yield. The increase in cluster weight is probably the consequence of increased berry size due to yield compensation. 
The reduced yield and improved the berry quality of grapes achieved by cluster thinning has been previously reported by (Keller et al., 2005; Sun et al. 2012 and Karoglan et al., 2014).

\section{Conclusion}

It could be concluded that to improve cluster and berries quality we can make berry thinning as removing $15 \%$ of cluster shoulders along with cutting back $15 \%$ from the apical cluster or cutting back about $30 \%$ of the apical portion of cluster.

\section{References}

A.O.A.C. 1985. Association of Official Agricultural Chemists. Official Methods of Analysis. A.O.A.C. $14^{\text {th }}$ Ed. Published by A.O.A.C. Washington, D.C. (U.S.A.).

Abd El-Galil, H.A.A. and M.M. ElWasfy. 2003. Effect of some cultural practices on King's Ruby grapevines production under Assiut conditions. C- Effect of thinning treatments on yield and berry quality. Assiut J. Agric. Sci., 34 (6): 207-219.

Cheema, S.S.; P. Singh and W.S. Dhillon. 2003. Effects of crop regulation and canopy management on fruit quality and disease incidence in grape. Indian J. of Hort., 60 (3): 208-213.

Coombe, B.G. and M.G. McCarthy. 2000. Dynamics of grape berry growth and physiology of ripening. Aust. J. Grape Wine Res., 6: 131-135.

Dhillon, W.S. and A.S. Bindra. 2002. Effect of berry thinning on quality and storage of grapes cv. Perlett. J. of Research Punjab Agric. Univ., 39 (2): 184-189.

Dhillon, W.S.; A.S. Bindra; S.S. Chefma and S. Sohan. 1992. Note on effect of berry thinning on quality of grapes cv. Perlette. Indian J. of Hort., 49 (1): 50-52.

Diago, M.P.; M. Vilanova and J. Tardaguila. 2010. Effect of timing of manual and mechanical early defoliation on the aroma of Vitis vinifera L. Tempranills wine. Ann. J. Enol. Vitic. 61 (3): 382-391.

El-Hammady, A.M.; A.D. Shaltout; N. Abdel-Hamid and M. El-Sayed. 2000. Effect of sitofex (CPPU) and shoulder thinning on yield and quality of King's Ruby grapes. Arab Univ. J. of Agric. Sci., 8 (3): 735-754.

El-Salhy, A.M.; H.M. Marzouk and A. Mohamed. 2010. Effect of some fruit improving treatments on Ruby and Thompson seedless grapevines productivity. Assiut J. Agric. Sci., 41 (3): 29-42.

FAO. 2014. Food and Agriculture Organization Statistical Year Book. FAO. Rome Italy.

Fitzgerald, J. and W.K. Patterson. 1994. Response of "Reliance" table grape to canopy management and ethephon application. J. Amer. Soc. Hort. Sci. 119 (5): 893-898.

Gomez, K.A. and A.A. Gomez, 1984. Statistical Procedures for Agriculture Research. $2^{\text {nd }}$ Ed. Wily, New York.

Hussein, Maha, M.A. 2008. Physiological studies on yield and fruit quality of some seedless grapevines cultivar. Ph.D. Thesis, Fac. Agric., Assiut Univ., pp. 261.

Karoglan, M.; M. Osrecak; L. Maslov and B. Kazina. 2014. Effect of cluster and berry thinning on Merlat and Cabernet sauvignon vine composition. Czech J. Food Sci. 32 (5): 470-476.

Keller, M.; L.J. Mills; R.L. Wampler; S.E. Spayed. 2005. Cluster thinning effects on three deficitirrigated Vitis vinifera cultivars. 
American Journal of Enology and Viticulture, 56: 91-103.

Kokl, O. and E. Ball. 2017. Chemical and non-chemical thinning treatments influence berry growth and composition on cv. Shiraz wine grape ( $V$. vinifera L.). DOI 0.1007/s10341-017-0321-2.

Marrkham, K.P. 1982. Techniques of flavonoids identification Academic Press, London.

Mohsen-Abeer, T. 2005. Effect of the thinning methods on Flame Seedless grapes on yield and fruit quality. J. Agric. Sci. Mansoura Univ., 30 (4): 2159-2166.

Palliotti, A. and A. Cartechini. 2000. Cluster thinning effects on yield and grape compositon in different grapevine cultivar. Acta Hort. 512: 111-119.

Petrie, P.R. and P.R. Clingeleffer. 2006. Crop thinning hand versus from irrigated Cabernet Sauvignon (Vitis vinifera L.) in a warm climate. Aust. J. Grpe Wine Res., 12: 21-29.

Poni, S. 2003. Summer pruning in vineyards: physiological and cultural aspects. Informatore Agrario, 59 (26): 37-49.

Rizk, M.H. 1998. Effect of sitofex (CPPU), $\mathrm{GA}_{3}$ and hand thinning on yield and fruit quality of Thompson seedless grapes. J. of Agric. Sci., Mansoura Univ., 23 (1): 397-404, Egypt.
Seleem, Basma, M. 2001. Productivity improvement of Roomy Red grape under Assiut conditions. Ph.D. Thesis, Fac. of Agric., Assiut Univ., Egypt, 124 p.

Singh, B. and N. Singh. 2003. Effect of mechanical and chemical treatments on the quality of Perlette grapes. Environment and Ecology. 21 (4): 755-758.

Snedecor, G.W. and W.G. Cochran, 1990. Statistical Methods $7^{\text {th }}$ ed. Iowa State Univ. Press. Ames.

Sun, Q.; G.L. Sacks; S.D. Lerch and J.H. Vanden Heuvel. 2012. Impact of shoot and cluster thinning on yield, fruit composition and vine quality of carot noir. American J. of Enology and Viticulture, 63: 49-56.

Tardaguila, J.; P.R. Petrie; S. Poni; M.P. Diago and F. Martinez de Toda. 2008. Effects of mechanical thinning on yield and fruit composition of Tempranillo and Grenache grapes trained to a vertical shoot positioned canopy. Am. J. Enol. Vitic. 59: 412-417.

Vicente, A. and J. Juste. 2015. Cluster thinning in cv. Verdejo rained grown: physiologic, agronomic and qualitative effects in the D.O. Rueda (Spain). Bio Web. of Conferences 5, 01020.

Winkler, A.J.; A.J. Cook; W.M. Kliewer and L.A. Linder. 1974. General viticulture. Published by University of California Press, Barkley. 
تأثير طرز الخف علي إثمار العنب الروبي عليم البذور

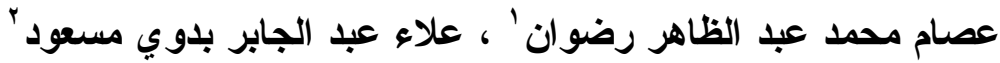

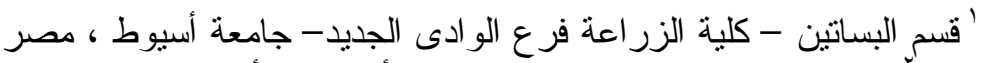

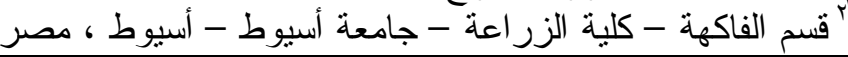

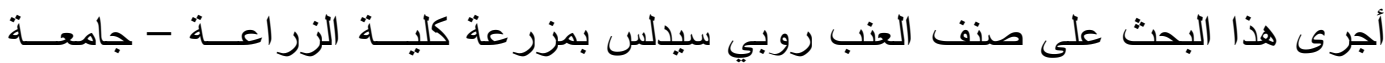

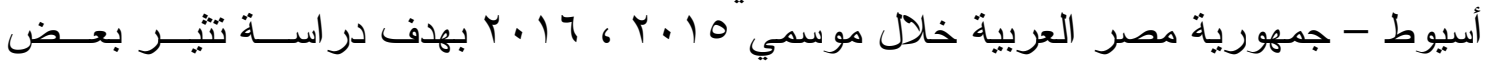

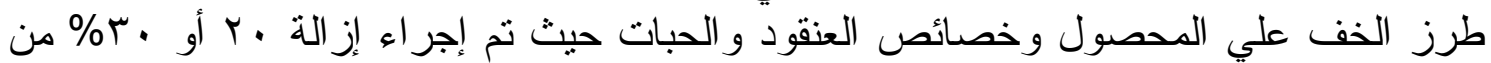

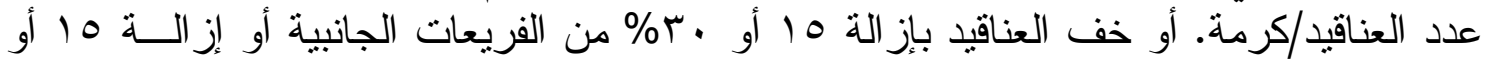

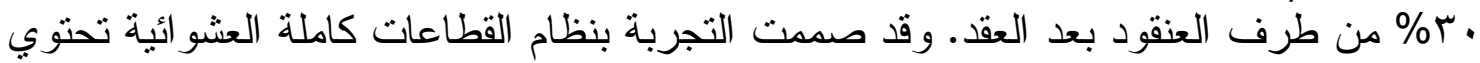

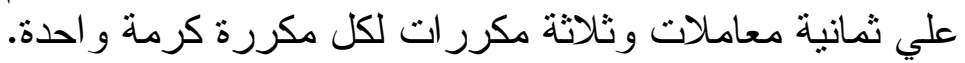

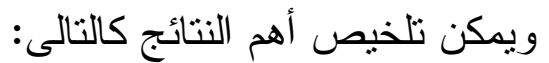

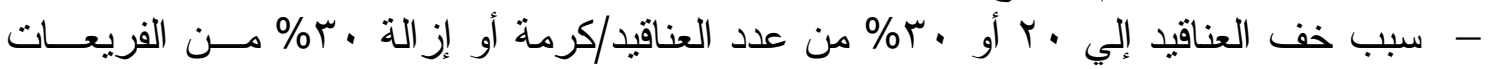

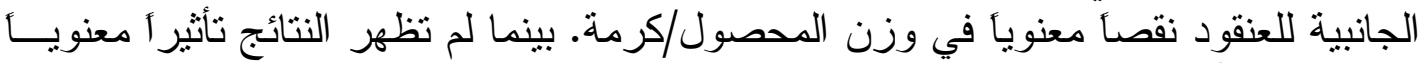

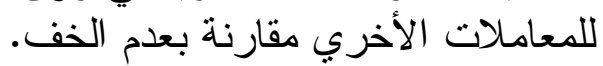

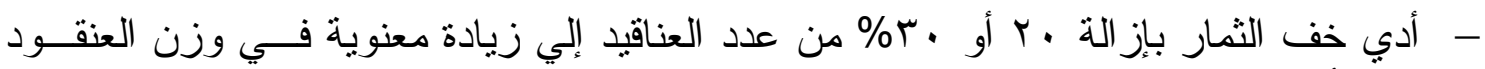

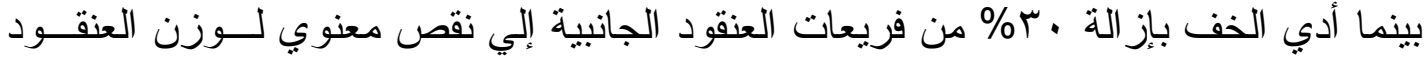
مقارنة بعد الخف.

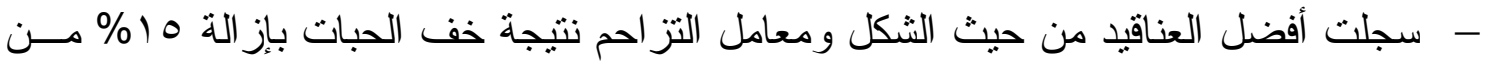

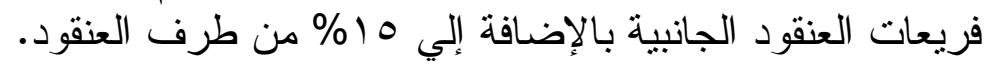

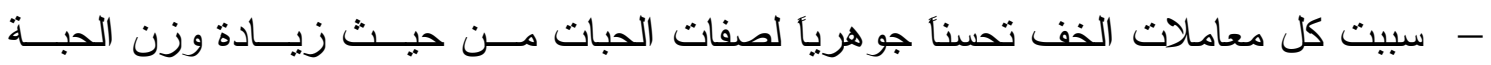

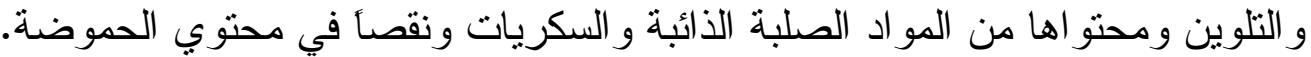

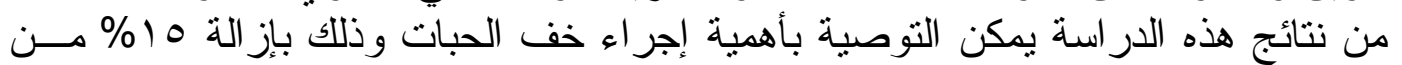

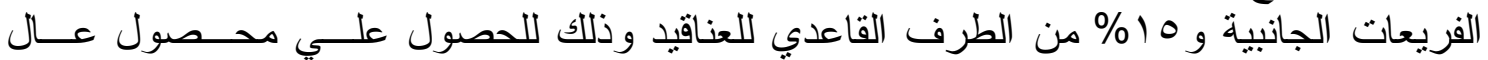
وصفات جيدة للعناقيد و الحبات. 